\title{
DEVELOPMENT OF INDONESIAN WORK READINESS SCALE ON FRESH GRADUATE IN INDONESIA
}

\author{
Marisa P. Sagita ${ }^{1}$, Azhar E. Hami², Zahrotur R. Hinduan² \\ ${ }^{1}$ Master Program, Faculty of Psychology, Padjadjaran University, \\ Jl. Raya Bandung Sumedang KM 21, Jatinangor, Sumedang, West Java, Indonesia 45363 \\ ${ }^{2}$ Faculty of Psychology, Padjadjaran University, \\ Jl. Raya Bandung Sumedang KM 21, Jatinangor, Sumedang, West Java, Indonesia 45363 \\ marisa17001@mail.unpad.ac.id
}

\begin{abstract}
Fresh graduates need to have work readiness as one of the essential attributes. Work readiness is a condition when fresh graduates ready to succeed in the working world. In Indonesia, studies explaining the measurement scale of work readiness are still limited. This study aims to develop a work readiness scale for undergraduates, which is beneficial for companies, universities, and fresh graduates. The research sample consists of 118 fresh graduates, with no prior work experiences. After several examinations, the scale contains 49 items. As a result, the construct validity test using confirmatory factor analysis (CFA) shows that the developed instrument can measure the work readiness construct. The results of the reliability test using Cronbach's alpha coefficient is .961. This number means that the developed instrument is reliable. The analysis results show that the developed work readiness scale has good validity and reliability.
\end{abstract}

Keywords: measurement; work readiness; fresh graduate; scale; validation

\begin{abstract}
Abstrak
Work readiness merupakan salah satu atribut yang perlu dimiliki sarjana baru. Work readiness yaitu keadaan ketika sarjana baru merasa siap dan sedia untuk sukses di lingkungan kerja. Di Indonesia, sampai saat ini studi yang menjelaskan pengukuran work readiness itu sendiri masih terbatas. Penelitian ini bertujuan untuk mengembangkan work readiness scale untuk para sarjana sehingga dapat berguna baik untuk perusahaan, perguruan tinggi maupun para sarjana tersebut sendiri. Sampel penelitian terdiri dari 118 sarjana baru yang belum pernah bekerja. Alat ukur terakhir berisi 49 item. Hasilnya, dengan uji validitas berdasarkan struktur internal menggunakan confirmatory factor analysis (CFA) menunjukkan bahwa alat ukur yang dikembangkan mampu mengukur konstruk work readiness. Hasil uji reliabilitas menggunakan cronbach's coefficient alpha yaitu 0,961 yang berarti alat ukur yang dikembangkan reliabel. Hasil analisis menunjukkan bahwa pengembangan alat ukur work readiness ini memiliki validitas dan reliabilitas yang baik.
\end{abstract}

Kata kunci: pengukuran; kesiapan kerja; sarjana baru; skala; validasi

\section{INTRODUCTION}

A new graduate or fresh graduate is a person who just recently graduated from an undergraduate level and has no prior work experience. Fresh graduates will soon confront the world of work. So, it is necessary to have excellent theoretical and practical understanding. In general, because they do not have prior work experience, they tend to have a minimal overview of the working world (Caballero \& Walker, 2010), are unfamiliar with the field of work, interest, and abilities (Sulastiana \& Sulistiobudi, 2017). Before entering the world of work, fresh graduate will compete not only with other new graduates but also with applicants having previous work experience. 
A fresh graduate experiences a transition from the university to the working world, from a student to a worker. They need to have some skills or attributes to adjust to the new world. These skills include the ability to work, organize, build relationships, and other attributes they do not receive from the college. Prikshat et al. (2018) state that companies consider that new graduates do not have practical skills. Besides, Tulu (2017) states that new graduates have skills, knowledge and practical experience that still do not meet company expectations.

Docherty \& Fernandez (2014) states that companies need workers who can adapt and mobilize from their prospective employees. Caballero \& Walker (2010) explained that there is a gap between company expectations and new graduates in personal and interpersonal skills. In selecting employees, companies in Indonesia more emphasis on potential and competencies for a specific job regardless of prospective employees' readiness. Work readiness can affect success at work.

In Indonesia, Priyono (2019) research the fresh graduates' work readiness in entering the world of work from various stakeholders' perspectives, such as government, companies and education providers. Priyono's research (2019) find that Indonesia has a significant gap between the discrepancy of industrial needs and the ability of new graduates. These gaps lie in self-confidence, character, personal integrity, analytical skills, problem-solving, communication and teamwork, time management, work sequences, creativity, and team orientation (OECD, 2016; UNESCO, 2012; World Bank, 2010). Berlingieri \& Erdsiek (2012) also find that fresh graduates with no work experience lack many skills expected by companies and enables the occurring of problems. The results of these studies become an essential issue for the discussion about the graduates' readiness to enter the world of work. It is necessary to measure the readiness of new graduates to enter the workforce. Based on this condition, a measuring instrument is needed to measure and explain the conditions of job readiness on new graduates in Indonesia. The fit concept explaining work readiness following the condition of new graduates in Indonesia is the work readiness from Caballero and Walker (2010).

Work readiness is the first qualification for entry-level workers. Graduates need to have practical and academic readiness in carrying out work task and responsibilities, which will ultimately support work performance and success in the 21st century (Lau et al., 2018). Sawitri \& Dewi (2018) state that individuals in the emerging adulthood stage will perceive their ability in achieving a job qualification and support them in decision making about work. Fresh graduates generally at this stage perceive their ability to work at the new targeted company. Companies have special attention related to work readiness; namely, learned skills in universities that can contribute to achieving company targets (Deloitte, 2015). Work readiness is an essential factor in understanding the transition from university to the working world (Prikshat et al., 2019). According to Cavanagh et al. (2015), work readiness is an essential skill.

Caballero and Walker (2010) developed the concept of work readiness which refers to the work readiness of new graduates in Australia. This study aims to develop a work readiness measurement tool based on the concept and context of Caballero and Walker. This concept specifies aspects and attributes that are unlearned during college but are essential attributes for job readiness and job success.

Personal attributes such as the ability to build a relationship, work competence and organizational skills are factors that determine work readiness (Caballero \& Walker, 2010). Work readiness is the degree to which 
undergraduates are considered to have attitudes and attributes that lead them ready to achieve success in the working world (Caballero et al., 2011). Work readiness is a new concept and still needs development. Before Caballero and Walker (2010) develop the concept of work readiness, several researchers had different terms and attributes in shaping the concept of work readiness. In some literature, work readiness refers to workforce readiness, work preparedness, graduate employability (Atlay \& Harris, 2000; Casner-Lotto et al., 2006; Gardner \& Liu, 1997; Hart, 2008). Caballero and Walker (2010) develop work readiness notion based on the development of previous concepts. According to Caballero and Walker (2010), many previous ideas are very similar and overlap between one attribute and another, which indicates the work readiness of fresh graduates.

The concept of work readiness is difficult to distinguish from employability. Employability explains how individuals perceive career success with a definition coming from themselves and is influenced by non-technical abilities including career self-management, professional identity, and social capital as well as external factors (Clarke, 2017). In contrast to employability, work readiness describes how individuals perceive skills proficiency that prepares individuals to survive and thrive in the workplace (Jackson \& Chapman, 2012).

Work readiness is a multidimensional concept that describing the attributes and characteristics of previously developed concepts. Caballero et al. (2011) develop a work readiness concept with four factors constructing work readiness. First, Personal Characteristic refers to how individual perceptions of their characteristics relate to work situations. Organizational Acumen refers to organizational knowledge and awareness of protocols and practices in the work environment. Work Competence focuses on individual strengths and comprehensive competencies related to work. Lastly, Social Intelligence refers to social skills and how individuals can adapt and interact in work situations. Australia Council for Educational Research also develops the work readiness concept with several factors, such as critical thinking, problem-solving, interpersonal understanding and written communication. Caballero et al. (2011) have explained all these factors in their work readiness concept through the competence and social intelligence aspects.

Several studies developed the concept of work readiness from Caballero and Walker (2010) with many different contexts. These studies are research on work readiness in teachers candidate in Australia (Heck, 2017), students majoring in Management in Australia (Chavan \& Carter, 2017), teachers in Croatia (Kokic and Blazevic, 2016), the military context in Africa (van Dyk, 2016), students at Research University, United States (Doe, 2015), students majoring in Business and Engineering in Malaysia (Tanius \& Susah, 2013; Makki et al., 2016). Mashigo (2014) conducted a study on antecedents and factors affecting work readiness using Caballero and Walker (2010) 's concepts. Masole and van Dyk (2016) conduct an exploratory study of the factors affecting work readiness in undergraduate and postgraduate social science students. There are also qualitative and quantitative studies on the effectiveness of Bachelor degree programs provided by Australian universities to develop work readiness for students (Borg et al., 2017; Jackson, 2019).

Besides, there are several studies to develop work readiness scales in specific contexts in several countries, such as study in undergraduate nursing schools (Walker et al., 2015), high school graduates majoring in Home Economics (Cabrera, 2020), and health professional graduates including medicine, dentistry and pharmacy (Aznal et al., 2019). Coetzee (2014) conduct the development and validation of the GSAS (Graduate Skill and 
Attribute Scale) for students and workers in early careers at the service industry in South Africa.

This study aims to develop a work readiness measurement tool in Indonesia based on the concept developed by Caballero and Walker (2010). Researchers expect that the measuring instrument can measure and predict fresh graduates' work readiness. Work readiness indicates new graduate capability for long-term performance and career advancement. Previously, Caballero et al. (2011) developed a work readiness measurement tool based on a concept known as the Work Readiness Scale. Measuring the work readiness of new scholars in Indonesia apart from their theoretical knowledge is necessary. This measurement supports the new graduates' readiness to enter new situations and conditions in the company, regardless of the situation and conditions in the university environment.

The development of this measuring instrument is expected to support companies in selection planning to measure the applicants' work readiness with new graduates' background. Besides, this instrument can be advantageous for measuring the work readiness of students or undergraduates in tertiary institutions as well as determining programs to prepare students to be ready in facing the working world. The work readiness instruments can also be a reference for new graduates to prepare themselves entering the work environment.

In Indonesia, several studies related to work readiness for new graduates are already conducted. Sawitri (2018) research selfperceived employability in students. The researchers found that students perceive themselves to be able to get a job following their qualifications when they have career aspirations and self-regulation. Besides, research from Sulastiana and Ashriyana (2017) examines psychological readiness, and job readiness training in improving new graduates work readiness. A study by Fathoni et al. (2019) consider increasing competitiveness and work readiness with vocational school education programs for final year students. The studies' result shows that more extended work experience and school period will increase competitiveness and work readiness. Also, there is research on antecedents and consequences of work readiness. Harahap \& Sagala (2019) found that emotional intelligence affects work readiness in paramedical students. Pratama \& Sagala (2018) found the effect of work readiness on career development in diploma and undergraduate students. However, no research has explicitly developed an instrument to measures the work readiness of new graduate and how a new graduate perceives himself to have attributes indicating work readiness.

This study develops a work readiness scale from Caballero and Walker's (2010) concept for new graduates in Indonesia. This research is a preliminary study aiming to develop and validate measuring instruments; thus, it is beneficial for various parties such as companies, higher education institutions and new graduates.

\section{METHOD}

The data collection aims to test the work readiness measurement tool, psychometric properties checking, namely, by considering reliability and validity. This study will conclude about the instrument validity and reliability.

\section{Participants and Sampling Procedure}

Total participants in this study are 118. Participants are new graduates with no prior work experiences. Researchers use convenient sampling technique to collect the sample. It is a technique of obtaining samples by considering the subjects' availability the ease 
of collecting data. Following is the demographic data of research respondents:

Table 1.

Demographic of Respondents

\begin{tabular}{ccc}
\hline \multicolumn{2}{c}{ Demographic of Respondents } & $f$ \\
\hline \multirow{2}{*}{ Categories } & 43 \\
& Male & 75 \\
\hline & Female & 14 \\
& Psychology & 7 \\
& Agriculture & 10 \\
& Business & \\
Economics & 10 \\
Major field & Law & 10 \\
of study & Informatics & 7 \\
& Nathematics and & \\
& Technic & 24 \\
& Social Science and & 8 \\
& Political Science & \\
& Communication & 10 \\
& Studies & \\
& Pharmacy & 9 \\
& Health Sciences & 9 \\
\hline
\end{tabular}

\section{Data Collection}

Data is collected online using a web pagebased self-completion questionnaire from Google (google form).

\section{Research Procedure}

The process of the work readiness' instrument development includes design and evaluation phases (Kerlinger, 2006). The design phase of this research is a literature review, considering the suitable work readiness' concept for Indonesia. The concept of Caballero and Walker (2010) fits the context of new graduates in Indonesia and has been used in various studies. The second phase includes operationalization of the work readiness concept, such as finding the indicators of each work readiness factor, developing item, and testing items. Meanwhile, the evaluation phase includes testing the validity, reliability and revising items.
The researchers start the instrument development with a literature study on work readiness. Work readiness is the degree to which undergraduates are considered to have attitudes and attributes that lead to success in the work environment (Caballero \& Walker, 2010). Based on this conceptual definition, the researcher operationalizes the definition into the attitudes and attributes of the new graduate showing that the new graduates are ready to succeed in the world of work.

Researchers develop items by setting indicators of four work readiness factors. The four factors of work readiness are personal characteristic, organizational acumen, work competence, social intelligence. Personal characteristic speaks about an individual's perception of his or her characteristics concerning work situations. Organizational acumen relates to organizational knowledge and awareness of protocols and practices in the work environment. Work competence focuses on individual strengths and comprehends competencies related to work. Social Intelligence refers to social abilities and the way individuals can adapt and interact socially in work situations.

After developing the statement items, researchers review the items through three new graduates. After conducting a review, the researchers test the instrument three times to obtain the distinguishing power and the appropriate loading factor value for each item so that the developed instrument is reliable and has a fit model. If there is an item with distinguishing power $<.3$, the item will be dropped. Besides, if the item has a loading factor of $<.5$, the item will also be removed.

\section{Data Analysis}

The researcher begins the test by measuring the overall reliability of the instrument and the 
reliability per factor. Items with no excellent discriminating power will be dropped. The next step is testing the validity with First Order Confirmatory Factor Analysis. Items with a loading factor of .4 are considered (Sharma, 1996) good and a t-value must be greater than 1.96 because it indicates that these factors can describe the measured construct (Simanjuntak et al., 2019). The next stage is to re-test the reliability based on the remaining items and test the validity (construct validity) with Second-Order Confirmatory Factor Analysis. Apart from validity, Second-Order Confirmatory Factor Analysis can also test reliability (construct reliability). The number of research subjects is 118 , with the criteria of being new graduates and have no prior work experience.

Total prior items are 61 items, with the following specifications: personal characteristic 11 items, organizational acumen 21 items, work competence 17 items, and social intelligence: 12 items. The response options use a rating scale of 1 - 6 (very inappropriate - very appropriate). Subjects are asked to choose the best suited and described themselves. Here is an example of an item for each work readiness factor:

Table 2.

Item Sample

\begin{tabular}{|c|c|}
\hline Factors & Items \\
\hline $\begin{array}{c}\text { Personal Characteristic } \\
\text { The way individuals perceive their characteristics } \\
\text { relate to work situations }\end{array}$ & $\begin{array}{l}\text {-I want to learn new things so I can do a good } \\
\text { job. }\end{array}$ \\
\hline Organizational Acumen & -I need to learn the company's organizational \\
\hline $\begin{array}{l}\text { Organizational knowledge and awareness of protocols } \\
\text { and practices in the work environment }\end{array}$ & structure and its bureaucracy. \\
\hline $\begin{array}{l}\text { Work Competence } \\
\text { Individual strengths and overall job-related } \\
\text { competences }\end{array}$ & $\begin{array}{l}\text {-I understand the knowledge I will use in my } \\
\text { work. }\end{array}$ \\
\hline $\begin{array}{c}\text { Social Intelligence } \\
\text { Social skills and the way individuals adapt and } \\
\text { interact socially in work situations }\end{array}$ & $\begin{array}{l}\text {-I realized that there are differences in the new } \\
\text { environment (workplace) with the previous } \\
\text { environment (college) so I have to adjust. }\end{array}$ \\
\hline
\end{tabular}

According to Friedenberg (1995), an excellent measuring instrument must be reliable and valid. A reliable instrument means consistent in measuring the individuals' knowledge who fulfill or complete the instrument. This study uses internal consistency reliability, considering the internal consistency. The items in the instrument draw the same knowledge or personal characteristics. The reliability test uses the Cronbach's alpha coefficient and considering the differentiating power of items with discriminant items using the SPSS 20.0. This study uses confirmatory factor analysis to measure reliability. Construct reliability measurement uses loading factors and measurement error of each item. The reliability of the measuring instrument is reliable if the coefficient is more than .700 (> .700).

This study also analysed discrimination power analysis or item discrimination on each item to examine the extent to which different subjects answer the items in different ways (Kerlinger, 2006). The distinguishing power of items is obtained from the corrected total item correlation value from the reliability test results. The criteria for discriminant items, according to Ebel and Frisbie (1991) are as 
follows:

Table 3.

Item Distinguishing Power Criteria (Friedenberg, 1995)

\begin{tabular}{cc}
\hline Item Discriminant Size & Classification \\
\hline$\leq .199$ & Poor \\
$.20-.299$ & Marginal \\
$.30-.399$ & Reasonably Good \\
$\geq .40$ & Very Good \\
\hline
\end{tabular}

A valid measuring instrument means measuring the characteristics relevant to the construct to be measured (Kerlinger, 2006). This study uses validation based on internal structure. This validation considers the extent to which the internal components of the test match the construct to be measured. The confirmation of validation is through Confirmatory Factor Analysis (CFA) using the LISREL 8.80 Full Version program, and the analysis uses path analysis. The criteria for validity through CFA are criteria from $\mathrm{Hu}$ and Bentler (1998) as the Fit criterion. The Fit criteria used include:

\section{Table 4.}

Fit Criteria

\begin{tabular}{ccc}
\hline & Criteria & Description \\
\hline$p$-value & $p$-value not significant $(p>.05)$ & Good Fit \\
& $<.05$ & Good Fit \\
RMSEA & $.05-.08$ & Fair Fit \\
& $>.1$ & Poor Fit \\
Chi-Square & $\leq \mathrm{df}$ & Good Fit \\
NFI & $\geq .9$ & Good Fit \\
NNFI & $.8-.9$ & Marginal Fit \\
CFI & $\geq .9$ & Good Fit \\
& $\geq .9$ & Good Fit \\
SRMR & $.8-.9$ & Marginal Fit \\
& $\geq .9$ & Good Fit \\
GFI/AGFI & $.8-.9$ & Marginal Fit \\
& $.8-.9$ & Good Fit \\
\end{tabular}

\section{RESULTS AND DISCUSSION}

The researchers conduct a validity test by measuring the construct validity, measuring the extent to which the internal components of the measuring instrument match the construct to be measured. The validity testing technique was performed by using Second-Order Confirmatory Factor Analysis (CFA) using LISREL 8.80 Full Version, with path analysis. Path analysis is a statistical analysis based on a system of equations to see the causal relationship between two or more variables. The validity criteria through CFA is an analysis to see the relationship between the dependent variable, and from $\mathrm{Hu}$ and Bentler (1998) as the Fit criterion. The path diagram displays the significance value (t-value) and the factor loading value (loading factor) showing the relationship between latent variables and measurement indicators. In this case, the latent variable is the work readiness with the factors and items in each factor. If the t-value and loading factor meet the criteria described in the method section, then the measuring instrument is considered to have good enough validity to explain latent variables. In general, the $t$-value of each item has a significant contribution to the measured factor, and each factor has a significant contribution to work readiness. Figures 1 and 2 below are the path diagrams resulting from the Second Order Confirmatory Factor Analysis. 


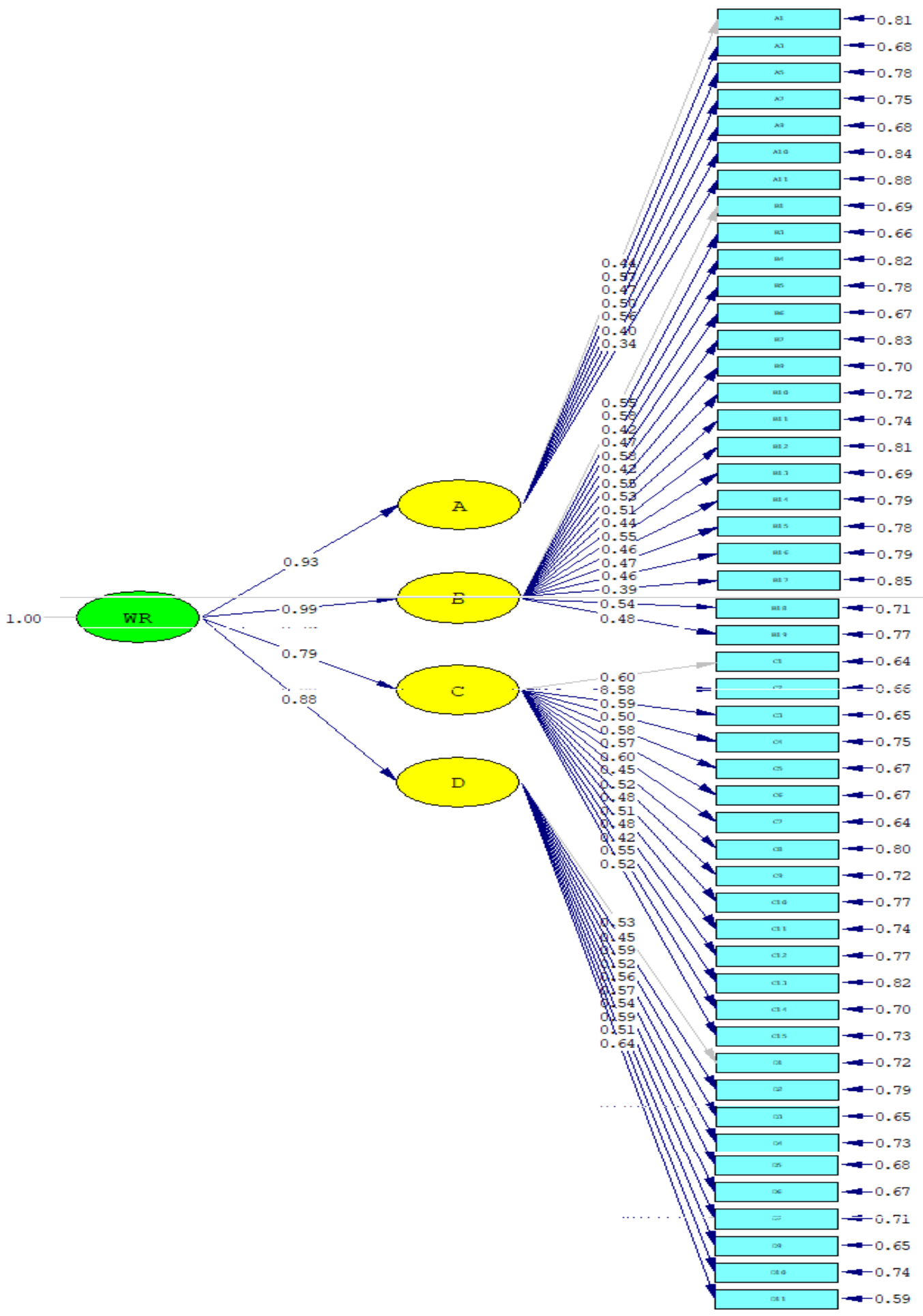

Figure 1. Loading Factor Second Order CFA of Work Readiness Scale 


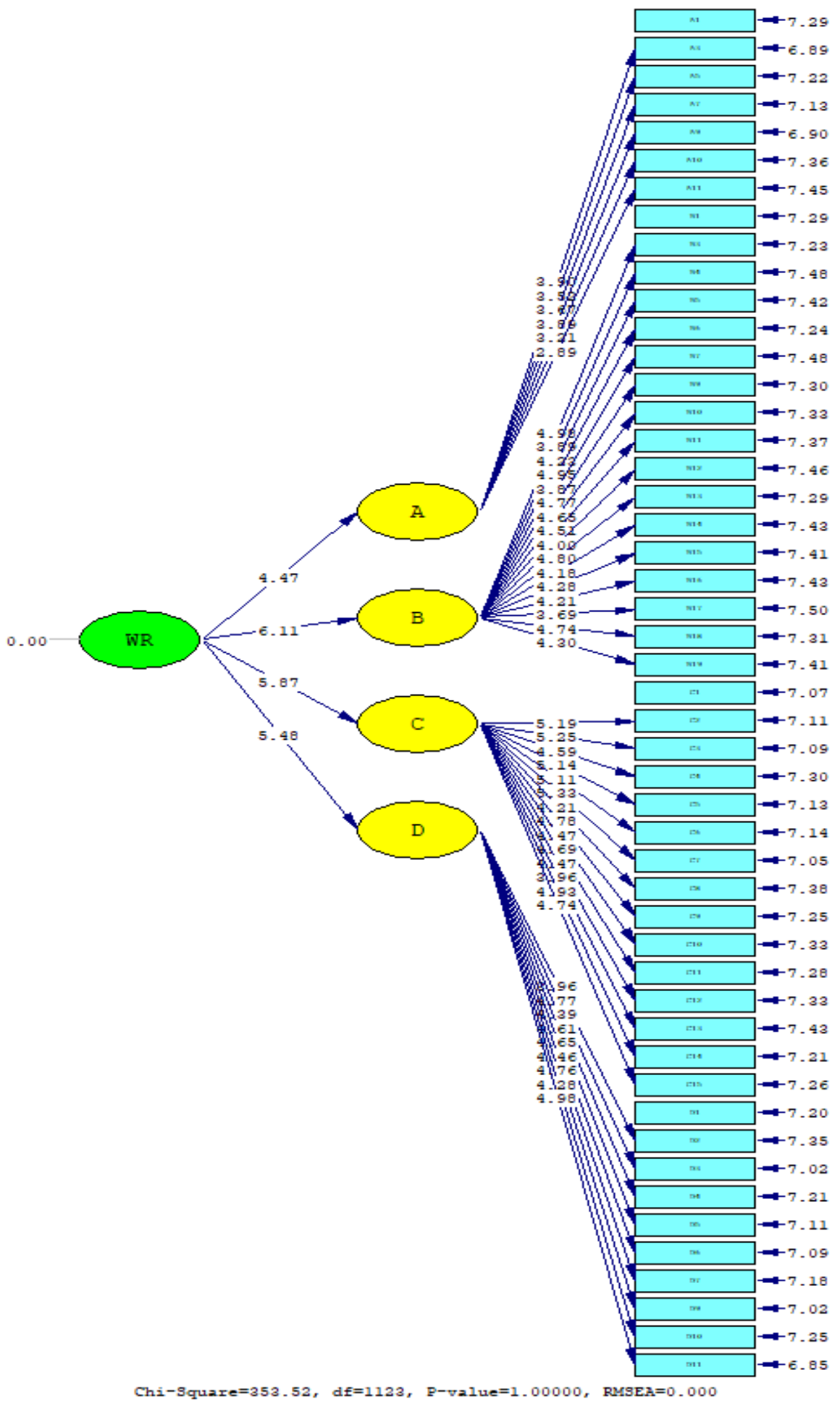

Figure 2. $t$-values Second Order CFA of Work Readiness Scale 
Figures one and two show the Second Order Confirmatory Factor Analysis. Figure one shows the loading factor, while Figure two shows the $t$-values. WR refers to Work Readiness, A) Personal Characteristic, B) Organizational Acumen, C) Work Competence, and D) Social Intelligence. Tables $5 \mathrm{a}$ and $5 \mathrm{~b}$ also demonstrate the loading factor values and $t$-values of the Second Order Confirmatory Factor Analysis that meet the criteria. These results indicate that the four work readiness factors are valid and significant for measuring the work readiness variable. Table 5 shows the results of the work item readiness analysis through the per-factor Second-Order Confirmatory Factor Analysis.

\section{Table 5a.}

First Order - Confirmatory Factor Analysis

\begin{tabular}{|c|c|c|c|c|}
\hline Factors & Loading Factor & $t$-values & $\begin{array}{c}\text { Measurement } \\
\text { Error }\end{array}$ & Description \\
\hline \multicolumn{5}{|c|}{ 1st Order CFA } \\
\hline \multicolumn{5}{|c|}{ Personal Characteristic } \\
\hline A1 & .44 & -- & .81 & Valid \\
\hline A3 & .57 & 3.90 & .68 & Valid \\
\hline A5 & .47 & 3.53 & .78 & Valid \\
\hline A7 & .50 & 3.67 & .75 & Valid \\
\hline A9 & .56 & 3.89 & .68 & Valid \\
\hline A10 & .40 & 3.21 & .84 & Valid \\
\hline A11 & .34 & 2.89 & .88 & Invalid \\
\hline \multicolumn{5}{|c|}{ Organizational Acumen } \\
\hline B1 & .55 & -- & .69 & Valid \\
\hline B3 & .58 & 4.98 & .66 & Valid \\
\hline B4 & .42 & 3.89 & .82 & Valid \\
\hline B5 & .47 & 4.23 & .78 & Valid \\
\hline B6 & .58 & 4.95 & 67 & Valid \\
\hline B7 & .42 & 3.87 & .83 & Valid \\
\hline B9 & .55 & 4.77 & .70 & Valid \\
\hline B10 & .53 & 4.65 & .72 & Valid \\
\hline B11 & .51 & 4.51 & .74 & Valid \\
\hline B12 & .44 & 4.00 & .81 & Valid \\
\hline B13 & .55 & 4.80 & .69 & Valid \\
\hline B14 & .46 & 4.18 & .79 & Valid \\
\hline B15 & .47 & 4.28 & .78 & Valid \\
\hline B16 & .46 & 4.21 & .79 & Valid \\
\hline B17 & .39 & 3.69 & .85 & Invalid \\
\hline B18 & .54 & 4.74 & .71 & Valid \\
\hline B19 & .48 & 4.30 & .77 & Valid \\
\hline
\end{tabular}


Table 5a (continued).

First Order - Confirmatory Factor Analysis

\begin{tabular}{|c|c|c|c|c|}
\hline Factors & Loading Factor & $t$-values & $\begin{array}{l}\text { Measurement } \\
\text { Error }\end{array}$ & Description \\
\hline \multicolumn{5}{|c|}{ 1st Order CFA } \\
\hline \multicolumn{5}{|c|}{ Work Competence } \\
\hline $\mathrm{C} 1$ & .60 & -- & .64 & Valid \\
\hline $\mathrm{C} 2$ & .58 & 5.19 & .66 & Valid \\
\hline $\mathrm{C} 3$ & .59 & 5.25 & .65 & Valid \\
\hline $\mathrm{C} 4$ & .50 & 4.59 & .75 & Valid \\
\hline $\mathrm{C} 5$ & .58 & 5.14 & .67 & Valid \\
\hline C6 & .57 & 5.11 & .67 & Valid \\
\hline $\mathrm{C} 7$ & .60 & 5.33 & .64 & Valid \\
\hline $\mathrm{C} 8$ & .45 & 4.21 & .80 & Valid \\
\hline $\mathrm{C} 9$ & .52 & 4.78 & .72 & Valid \\
\hline $\mathrm{C} 10$ & .48 & 4.47 & .77 & Valid \\
\hline $\mathrm{C} 11$ & .51 & 4.69 & .74 & Valid \\
\hline $\mathrm{C} 12$ & .48 & 4.47 & .77 & Valid \\
\hline $\mathrm{C} 13$ & .42 & 3.96 & .82 & Valid \\
\hline $\mathrm{C} 14$ & .55 & 4.93 & .70 & Valid \\
\hline $\mathrm{C} 15$ & .52 & 4.74 & .73 & Valid \\
\hline \multicolumn{5}{|c|}{ Social Intelligence } \\
\hline D1 & .53 & -- & .72 & Valid \\
\hline D2 & .45 & 3.96 & .79 & Valid \\
\hline D3 & .59 & 4.77 & .65 & Valid \\
\hline D4 & .52 & 4.39 & .73 & Valid \\
\hline D5 & .56 & 4.61 & .68 & Valid \\
\hline D6 & .57 & 4.65 & .67 & Valid \\
\hline D7 & .54 & 4.46 & .71 & Valid \\
\hline D9 & .59 & 4.76 & .65 & Valid \\
\hline D10 & .51 & 4.28 & .74 & Valid \\
\hline D11 & .64 & 4.98 & .59 & Valid \\
\hline
\end{tabular}

Table 5b.

Second Order - Confirmatory Factor Analysis

\begin{tabular}{cccc}
\hline Factors & Loading Factor & $t$-values & Description \\
\hline 2nd Order CFA & & & \\
Work Readiness & & & \\
Personal Characteristic & .93 & 4.47 & Valid \\
Organizational Acumen & .99 & 6.11 & Valid \\
Work Competence & .79 & 5.87 & Valid \\
Social Intelligence & .88 & 5.48 & Valid \\
\hline
\end{tabular}


The $t$-values and loading factor of each factor in the Second Order Confirmatory Factor Analysis show that these factors describe the measured variable. The result means that Personal Characteristic, Organizational Acumen, Work Competence, and Social Intelligence factors are factors describing Work Readiness in new graduates in Indonesia. Researchers in Indonesia can use the results of this study to investigate the phenomenon of work readiness in Indonesia by using this successfully developed instrument.
Based on $\mathrm{Hu}$ and Bentler (1998), the criteria for determining the CFA Goodness of Fit is by considering the Root Mean Square Error of Approximation (RMSEA), chi-square, Goodness of Fit Index / Adjusted Goodness of Fit Index (GFI / AGFI), Standardized Root Mean Square Residual (SRMR), Comparative Fit Index (CFI) and Normed Fit Index (NFI). Table 6 shows the results of the goodness of fit Second-Order Confirmatory Factor Analysis originating from 118 subjects and 49 measuring instrument items.

Table 6.

Fit Model Analysis's Results of the Work Readiness Measurement Tool

\begin{tabular}{cccc}
\hline & Criteria & Result & Interpretation \\
\hline$p$-value & $p$-value not significant & 1.000 & Good fit \\
RMSEA & $<.05$ & .000 & Good Fit \\
Chi-Square/df & $<2$ & $353.52 / 1123=1.123$ & Good Fit \\
NFI & $\geq .90$ & .96 & Good Fit \\
NNFI & $\geq .90$ & 1.14 & Good Fit \\
CFI & $\geq .90$ & 1.00 & Good Fit \\
SRMR & $<.05$ & .043 & Good Fit \\
GFI & $\geq .90$ & .89 & Marginal Fit \\
AGFI & $\geq .90$ & .88 & Marginal Fit \\
\hline
\end{tabular}

Table 6 shows that in general, the work readiness measuring instrument developed has the goodness of fit index or is in the range indicating a good fit. Hair et al. (2014) state that a measurement model is fit when 3-4 fit criteria are met. In the table, it can be seen that there are seven fits met criteria. The goodness of fit and adjusted goodness of fit are at the marginal fit level, with the analysis results value approaching the good fit criteria. GFI or AGFI shows how close the model can replicate the covariance matrix from the data. GFI and AGFI tend to be influenced by the sample size, so it can be said that GFI or AGFI might tend to increase if the sample size is increased. These results indicate that the developed measuring instrument of the work readiness refers to the concept of Caballero et al. (2011) can be used as an instrument to measure the work readiness of new graduates.
Initial reliability coefficient test results (before CFA) was .948, more excellent than .700. Therefore, it can be concluded that the work readiness measuring instrument is reliable. Even so, a good measuring tool should have statistically good items (Kerlinger, 2006). Useful measuring items can differentiate between individuals. Based on the initial analysis, there are several items with poor differentiation. Based on the item discriminant criteria, there are two poor items, three marginal items, seven items reasonably good, and 49 items excellent. Based on the results of the reliability analysis, five items are dropped, namely items number $22,26,40,43,60$. Two items are from organizational acumen, two from work competence and one item from social intelligence. The number of items becomes 56 items. 
Researchers tested the reliability's back with Confirmatory Factor Analysis. The researchers examine reliability because seven items $(2,4$, $6,8,13,19,57)$ are dropped due to the unfulfilled loading factor. With a total of 49 items, the reliability test results show the number .961, reliable. The results of the analysis also show item discriminant, and there are no poor items, no marginal items, two reasonably good items, and 47 excellent items. With an average discriminant item of .579 , the lowest discriminant item was .347 , and the highest discriminant item was .739. In general, item discrimination shows that the work readiness measurement item meets the criteria of being a good item (Friedenberg, 1995). The total item after the last test is 49 items. In addition to the overall reliability test, the researchers test the reliability of each work readiness factor. Table seven shows Cronbach's alpha coefficient and construct reliability (CR) of work readiness and each of its factors.

Table 7.

Reliability

\begin{tabular}{cccc}
\hline & Items & $\begin{array}{c}\text { Cronbach's Coefficient } \\
\text { Alpha }\end{array}$ & $\begin{array}{c}\text { Construct Relability } \\
\text { (CFA) }\end{array}$ \\
\hline Work Readiness & $\mathbf{4 9}$ & $\mathbf{. 9 6 1}$ & $\mathbf{. 9 4 6}$ \\
Personal Characteristic & 7 & .761 & .665 \\
Organizational Acumen & 17 & .903 & .846 \\
Work Competence & 15 & .931 & .855 \\
Social Intelligence & 10 & .900 & .814 \\
\hline
\end{tabular}

The reliability estimation in the trial shows that the four work readiness factors have good reliability. All factors have a Cronbach's coefficient alpha of more than .700. Besides, construct reliability is also measured by calculating the loading factor and the number of measurement errors from the Second Order
Confirmatory Factor Analysis. Based on these calculations, the reliability result of the work readiness construct is .946 . This result indicates that the developed work readiness scale has good reliability. Table 8 shows the reliable and valid item numbers that can be used to measure work readiness.

Table 8.

Work Readiness Scale's Blueprint After Removing Several Items

\begin{tabular}{ccc}
\hline Aspects & $\begin{array}{c}\text { Number } \\
\text { of Items }\end{array}$ & Item Number \\
\hline Work Readiness & $\mathbf{4 9}$ & $1,3,5,7,9,10,11$ \\
Personal Characteristic & 7 & $12,14,15,16,17,18,20,21,23,24,25,27,28,29,30,31,32$ \\
Organizational Acumen & 17 & $33,34,35,36,37,38,39,41,42,44,45,46,47,48,49$ \\
Work Competence & 15 & $50,51,52,53,54,55,56,58,59,61$ \\
Social Intelligence & 10 &
\end{tabular}

Based on the reliability and validity results, the development of measuring instruments in this study is proven able to measure work readiness from the model of Caballero and Walker's
(2010). This measuring instrument is reliable; it means that this measuring instrument provides consistent results. This consistency explains that this tool is a reliable measure of 
the participants' knowledge or characteristics who have completed this scale (Friedenberg, 1995). This measuring instrument is proven valid based on the validity test results. Friedenberg (1995) states that a valid measuring instrument indicates that the instrument measures the characteristics that are relevant to the goal of the measurement. The analysis method for construct validity measurement uses confirmatory factor analysis. The results show that the developed instrument in this study measures what to measure. This instrument has a construction following the purpose of the measurement.

The results of this study prove that the factors in Caballero and Walker's (2010) work readiness are following the work readiness context of new graduates in Indonesia. The test results show that the items are related and describe the work readiness factors and also the factors describing the latent variables. The results of this study indicate that personal characteristics, organizational acumen, work competence, and social intelligence can describe the work readiness of fresh graduates in Indonesia. The result is in line with factors constructing the work readiness on new graduates in Indonesia, such as self-confidence and character (UNESCO, 2012), which are under personal characteristics. Personal integrity (UNESCO, 2012), time management and work sequences (OECD, 2016). ) relate to organizational acumen factors. Analytical skills, problem-solving (UNESCO, 2012) and creativity (World Bank, 2010) explain work competence factors. Finally, communication, cooperation and team orientation (UNESCO, 2012; World Bank, 2010) are included in the social intelligence factor. Based on this explanation, the concept of work readiness from Caballero and Walker (2010) is following the factors that shape work readiness in new graduates in Indonesia and the developed instruments in this study can be used in Indonesia.
This research has produced an instrument that can be used in Indonesia. Some stakeholders, such as universities and companies, can benefit this tool in employees selection, especially in measuring the work readiness of prospective employees. The results of this study can initiate other studies of work readiness phenomenon. So, it can be concluded that this measuring tool helps the development of work readiness research and practice in Indonesia.

\section{CONCLUSION}

Based on the phases of developing a work readiness measuring instrument from Caballero et al. (2011), this study succeeds in constructing measuring instruments that meet good criteria, namely being reliable, having good distinguishing power, and being valid regarding the internal structures. The work readiness scale can be used according to its purpose, namely examining the work readiness of new graduates. Bentler \& Yuan (1999, in Tabachnick \& Fidell, 2013) states that the minimum number of samples should be between 60 and 120. Researchers suggest that further studies include a larger sample, at least 200 (Singh et al., 2016) to 300 (Tabachnick \& Fidell, 2013) participants. Increasing the number of samples aims to increase validity proving. Besides, researchers also suggest that future studies consider the various factors affecting the measurement results so that measurements can provide more precise results.

\section{REFERENCES}

Atlay, M., \& Harris, R. (2000). An Institutional Approach to Deveoping Students 'transferable' Skills. Innovations in Education and Training International, 27(1), 76-84. doi:10.1080/135580000362115

Aznal, S. S., Nadarajah, V. D., Kwa, S. K., Seow, L. L., Chong, D. W., Molugulu, N., . 
. . Keng, P. S. (2019). Validation of a 'Work Readiness Scale' for Health Professional (HP) Graduates. Medical Teacher, 1-6. doi: 10.1080/0142159X.2019.1697434

Berlingieri, F., \& Erdsiek, D. (2012). How Relevant is Job Mismatch for German Graduates. ZEW - Centre for European Economic Research. Retrieved from http://ftp.zew.de/pub/zewdocs/dp/dp12075.pdf

Borg, J., Turner, M., \& Scott-Young, C. (2017). Fostering Students Work Readiness - A University Case Study. In M. Lamb (Ed.), AUBEA 2017 Conference Papers. 1, (pp. 196-209). Melbourne: RMIT University. doi:.29007/n8wn

Caballero, C., \& Walker, A. (2010). Work Readiness in Graduate Recruitment and Selection: A Review of Current Assessment Method. Journal of Teaching and Learning for Graduate Employability, 1(1), 13-25. doi:10.21153/jtlge2010vol1 no1 art546

Caballero, C., Walker, A., \& Fuller, T. (2011). The Work Readiness Scale: Developing a measure to assess work readiness in college graduates. Journal of Teaching and Learning for Graduate emloyability, 2(2), 41-54.

doi:10.21153/jtlge2011vol2no1art552

Cabrera, W. C. (2020). Development and Validation of Work Readiness Assessment Scale for Home Economics Graduates. Economics Development Research, 1(2), 70-109. doi: 10.37385/ijedr.v1i2.47

Casner-Lotto, J., Barrington, L., \& Wright, M. (2006). Are They Really Ready to Work? Employers' Perspectives on the Basic Knowledge and Applied Skills of New Entarns to the 21st Century U.S. Workforce. Washington DC: The
Conference Board, Inc., The Partnership for 21st Century Skills, Corporate Voices for Working Families, The Society for Human Resources Management. https://files.eric.ed.gov/fulltext/ED519465. pdf

Cavanagh, J., Burston, M., Southcombe, A., \& Bartram, T. (2015). Contributing to a Graduate-centred Understanding of Work Readiness: An Exploratory Study of Australian Undergraduate Students' Perception of Their Employability. The International Journal of Management Education, 13(3), 278-288. doi: 10.1016/j.ijme.2015.07.002

Chavan, M., \& Carter, L. (2018). Management Students - Expectation and Perceptions on Work Readiness. International Journal of Educational Management, 32(5), 825-850. doi: /10.1108/IJEM-10-2016-0219

Clarke, M. (2017). Rethinking Graduate Employability: The Role of Capital, Individual Attributes and Context. Studies in Higher Education, 43(11), 1923-1937. doi:10.1080/03075079

Coetzee, M. (2014). Measuring Student Graduateness: Reliability and Construct Validity of the Graduate Skills and Attributes Scale. Higher Education Research \& Development, 33(5), 887-902. doi:https://doi.org/10.1080/07294360.2014. 890572

Deloitte. (2015). Mind the gaps: The 2015 Deloitte Millenial Survey - Executive Summary. London: DTTL Global Brand \& Communication. Retrieved from http://www2.deloitte.com/content/dam/Del oitte/in/Documents/about-deloitte/in-about2015-millenial-innovation-survey.pdf

Docherty, D., \& Fernandez, R. (2014). Career Portofolios and the Labour Market for Graduates and Postgraduates in the UK. 
London: National Centre for Universities and Business.

Doe, R. (2015). Work Readiness among Graduate Students. Disertasi. Louisiana State University. https://digitalcommons.lsu.edu/gradschool_ dissertations/1008/

Ebel, \& Frisbie. (1991). Essential of Educational Measurement. New Delhi: Prentice Hall of India.

Fathoni, A., Rahmadyanti, E., Kusumawati, N., Muslim, S., Setiyono, S., \& Aribowo, W. (2019). Increased Competitiveness and Work Readiness of Students Four year Vocational High School (VHS). Indonesian Journal of Learning Education and Counseling, 1(2), 186-194. doi: 10.31960/ijolec.v1i2.114

Friedenberg, L. (1995). Psychological Testing: Design, Analysis and Use. Needham Heights, MA: Allyn \& Bacon.

Gardner, P. D., \& Liu, W. (1997). Prepared to Perform? Employers Rate Work Force Readiness of New Grads. Journal of Career Planning \& Employment, 57(3), 32-56.

https://pdfs.semanticscholar.org/1c18/0885 236cf4cfb4c221722b091eec51bd0fdc.pdf

Hair, J. F., Black, W. C., Babin, B. J., \& Anderson, R. E. (2014). Multivariate Data Analysis (7th ed.). Edinburg: Pearson.

Harahap, D. A., \& Sagala, E. J. (2019). Pengaruh Kecerdasan Emosional terhadap Kesiapan Kerja pada Mahasiswa Paramedic. AKUNTABEL, 26(1), 47-53. doi: 10.29264/jakt.v16i1.5391

Heck, D. (2017). Reframing the Research and Work Skills Development Framework Facets to Support Becoming a Teacher. Proceedings of the 2017 International Conference on Models of Engaged
Learning and Teaching (I-MELT) (pp. 110). Adelaide: University of Adelaide.

$\mathrm{Hu}$, \& Bentler. (1999). Cutoff Criteria for Fix Indexes in Covariance Structure Analysis. A Multidisciplinary Journal, 6(1), 1-55. doi:10.1080/10705519909540118

Kerlinger, F.N. (2006). Asas-Asas Penelitian Behavioral. Yogyakarta: Gadjah Mada University Press.

Jackson, D. (2019). Student Perception of the Development of Work Readiness in Australian Undergraduate Programs. Journal of College Student Development, 60(2), 219-239. doi: $10.1353 / \mathrm{csd} .2019 .0020$

Jackson, D., \& Chapman, E. (2012). Nontechnical Skill Gaps in Business Graduates. Education + Training, 54(2-3), 95-113. doi: 10.1108/00400911211210224

Kokic, I. B., \& Blazevic, I. (2016). Relationship between Teachers Entrepreneurial Competence, Level of Job Satisfaction and Work Readiness. In M. Matijevic, \& T. Ziljak (Ed.), 7th International Conference on Adult Learning Who Needs Adult Education? (pp. 80-87). Hrvatska: University of Split. Retrieved from https://www.researchgate.net/publication/3 21225715_The_Relationship_between_Tea chers_Entrepreneurial_Competence_Level _of_Job_Satisfaction_and_Work_Readines S

Lau, P. L., Baranovich, D.-L., \& Leong, K. (2018). Enhancing Work Readiness: A Review of Career Development of Adolescents in Malaysia. International Journal of Education, Psychology and Counseling, 3(8), 13-20. Retrieved from https://pdfs.semanticscholar.org/3b0f/befbe 41f5746f5510bc951fd9602558f1c8d.pdf 
Makki, B. I., Javaid, M. U., \& Bano, S. (2016). Level of Work Readiness Skills, Career Self-Efficacy and Career Exploration of Engineering Students. NFC-IEFR Journal of Engineering \& Science Research, 4(1), 91-96. doi:10.24081/nijesr.2016.1.0017

Mashigo, A. C. (2014). Factors Influencing Work Readiness of Graduates: An Exploratory Study. Tesis. Stellenbosch University. Retrieved from https://scholar.sun.ac.za/handle/10019.1/95 884

Masole, L., \& van Dyk, G. (2016). Factors influencing Work Readiness of Graduates: An Exploratory Study. Journal of Psychology in Africa, 26(1), 70-73. doi: 10.1080/14330237.2015.1101284

OECD. (2016). Skills Matter: Further Results from the Survey of Adult Skills. OECD Skills Studies. Paris: OECD. Retrieved from

https://www.oecd.org/skills/piaac/Skills_M atter_Further_Results_from_the_Survey_of _Adult_Skills.pdf

Pratama, R. A., \& Sagala, E. J. (2018). The Influence of Work Readiness towards Career Development (Study Case of Telkom University Diploma and Bachelor Graduates). e-Proceeding of Management, 5(2), 2469-2473. Retrieved from https://openlibrary.telkomuniversity.ac.id/p ustaka/files/143438/jurnal_eproc/theinfluence-of-work-readiness-towardscareer-development-study-case-of-telkomuniversity-diploma-and-bachelorgraduates-.pdf

Prikshat, V., Nankervis, A., Burgess, K., \& Dhakal, S. P. (2019). Conceptualising Graduate Work-Readiness: Theories, Concepts and Implications for Practice and Research. In The Transition from Graduation to Work, Work, Organization, and Employment (pp. 15-29). Singapore:
Springer. doi:10.1007/978-981-13-09748_2

Prikshat, V., Nankervis, A., Priyono, S., Moh'd Saleh, N., Connel, J., \& Burgess, J. (2018). Graduate Work Readiness Challenges in the Asia-Pacific region and the Role of HRM. Equality, Diversity, and Inclusion: An International Journal, 37(2), 121-137. doi:10.1108/EDI-01-2017-0015

Priyono, S., \& Nankervis, A. (2019). Graduate Work-Readiness Challenges in IndonesiaFindings from a Multiple Stakeholder Study. In S. Dhakal et al. (eds.), The Transition from Graduation to Work, Work, Organization, and Employment (pp. 107-123). Singapore: Springer Nature Singapore Pte Ltd. doi:10.1007/978-98113-0974-8_7

Sawitri, D. R., \& Dewi, K. S. (2018). Aspirasi Karir Regulasi Diri, dan Self-Perceived Employability pada Mahasiswa. Jurnal Psikologi, $\quad$ 17(1), 68-76. doi:10.14710/jp.17.1.68-76

Sharma, S. (1996). Applied Multivariate Techniques. New York: John Wiley \& Sons, Inc.

Simanjuntak, E., Fajrianthi, Purwono, U., \& Ardi, R. (2019). Skala Cyberlacking pada Mahasiswa. Jurnal Psikologi, 18(1), 55-68. doi:10.14710/jp.18.1.55-68

Singh, K., Junnakar, M.., Kaur, J. (2016). Measures of Positive Psychology, Development and Validation. Berlin: Springer.

Sulastiana, M., \& Sulistiobudi, R. A. (2017). Psychological Readiness \& Job Readiness Training: Membangun Kesiapan Sarjana Baru Untuk Bekerja. Jurnal Ilmiah Psikologi Terapan, 5(1), 1-18. doi:10.22219/jipt.v5i1.3836 
Tabachnick, B. G., \& Fidell, L. S. (2013). Using Multivariate Statistics. (6th, Ed.) Upper Saddler River: Pearson.

Tanius, E., \& Susah, S. (2013). Employability Skill Readiness among Business Students. International Journal of Science and Research (IJSR), 4(8), 511-515. Retrieved from

https://www.ijsr.net/archive/v4i8/SUB1572 94.pdf

Tulu, S. K. (2017). A Qualitative Assessment of Unemployment and Psychology Fresh Graduates' Job Expectation and Preference. Psychology and Behavioral Sciences, 6(2), 21-29. doi:/10.11648/j.pbs.20170602.12

UNESCO. (2012). Graduate Employability in Indonesia. In UNESCO 2012, Graduate Employability in Asia. Bangkok: UNESCO. Retrieved from https://unesdoc.unesco.org/ark:/48223/pf00 $\underline{00215706}$

van Dyk, G. A. (2016). Military Psychology for Africa. Stellenbosch: SUN MeDIA.

Walker, A., Storey, K., Costa, B., \& Leung, R. (2015). Refinement and Validation of the Work Readiness Scale for Graduate Nurses. Nursing Outlook, 63(6), 1-7. doi:10.1016/j.outlook.2015.06.001

World Bank. (2010). Indonesian Skills Report:Trends in skills demand, gaps and supply, in Indonesia. Washington: Human Development Department, World Bank. Retrieved from http://siteresources.worldbank.org/EASTA SIAPACIFICEXT/Resources/2263001279680449418/HigherEd_IndonesiaSkill Report.pdf 